\title{
Impact of Bitcoin as a World Currency
}

\author{
A.Seetharaman ${ }^{1}$, A.S.Saravanan ${ }^{2}$, Nitin Patwa ${ }^{3} \&$ Jigar Mehta $^{4}$ \\ ${ }^{1}$ Dean Academic Affairs, S P Jain School of Global Management - Dubai - Mumbai - Singapore - Sydney \\ ${ }^{2}$ Senior Lecturer, Taylors University Malaysia, Malaysia \\ ${ }^{3}$ Assistant Professor, Director of Simulations, S P Jain School of Global Management - Dubai - Mumbai - \\ Singapore - Sydney \\ ${ }^{4}$ Post Graduate Scholar, S P Jain School of Global Management - Dubai - Mumbai - Singapore - Sydney \\ Correspondence: Nitin Patwa, Assistant Professor, Director of Simulations, S P Jain School of Global Management - \\ Dubai - Mumbai - Singapore - Sydney
}

Received: April 4, 2017

doi:10.5430/afr.v6n2p230
Accepted: May 17, 2017

Online Published: May 23, 2017

URL: https://doi.org/10.5430/afr.v6n2p230

\begin{abstract}
In an era of technology advancement when the entire world is talking about the "Internet of Things" whereby we are expected to have connectivity between anything and everything, Currency cannot be left behind. Paper currency is bound to be a thing of past, as virtual currencies will start taking over and Bitcoin is well poised to achieve this feat. Not only it will revolutionize the way payments are made, but also have potential to impact the future of world currencies like USD, which is already facing challenges from EURO or Chinese Yuan Renminbi (CNY). The rise of crypto-currencies will add a new dimension to this challenge for US Dollar (USD)

The focus of this study is to understand multiple factors which are translating Bitcoin (BTC) that is gaining momentum in various fields of global finance and how disruptive it can be, including replacing main fiat currencies in the financial system impacting mainly USD. The key variables studied are Regulation or lack of it around Bitcoin, Bitcoin Technology, Bitcoin Economy and the usage of Bitcoin as a Currency. This research used the latest statistical tool ADANCO 1.1.1 by Henseler and Dijkstra (2015) to analyze the data collected by building a partial least squares structural equation model (PLS-SEM). The observations of this study will help understand the future of global finance from multiple standpoints, especially Regulation, Cryptocurrencies and the fiat currencies.
\end{abstract}

Keywords: Virtual currency, Bitcoin, Crypto-currencies, Payment systems

\section{Introduction}

USD as a world currency has survived for decades, though Japanese Yen did become increasingly popular as an international currency during the 1980s. Of late, both Chinese Renminbi and EURO are challenging the USD in the International Finance. It is also evident from the fact that the share of USD in the reserve currency is falling, though overall the Reserve Currency globally is increasing. However, neither Yuan nor EURO can compete strongly with USD due to its valuations problems, i.e. Chinese Yuan is considered as undervalued whereas EURO being as Overvalued (BHALLA, S.S 2011).

Although the Renminbi may indeed present a viable alternative at some point, for the foreseeable future the dollar will remain preeminent. The closest rival was the EURO, but since the crisis began in the region, EURO currency reserve accumulation has been decreasing (BEDELL, D., 2011). Similarly, Yuan lacks the primary prerequisite to becoming a global currency, i.e. free and full convertibility. If CNY wants to dominate, it will have to establish itself as a Regional Currency, which can be the first step towards internationalization (HOKROH, M.A 2013)

Another view about CNY is, it seems inevitable that by 2024 the RMB will indeed be playing a key role in global payments and banking and will have replaced the Japanese yen as the principal Asian currency (Chance G., 2014.). No currency is free of challenges in the global economic environment including USD. However, the US dollar will remain the world's reserve currency of choice as long as there is no credible alternative. Reserve currency countries enjoy exorbitant benefits like cheap borrowings. It cannot last longer as this resents other economies and therefore over a period emerging economies would either want to get themselves added to the list of dominant world currency or will start demanding an alternate currency altogether. The view supported by the announcement (Nov, 2015) by the International Monetary Fund to include China's Yuan, or Renminbi, as it's also known, in an exclusive group of 
currencies that make up the basket of the IMF's. Special Drawing Rights (SDR) is seen as a positive development for the CNY. Inclusion represents USD's weakening in its global position and acknowledgment of Chinese Renminbi' strength in the global economy.

Fariborz had mentioned about a discussion that in the 21st century, more comprehensive financial market integration and a single global currency could emerge (Fariborz M., 2007). There are discussions on the formation of a global currency area (GCA), which would signal the natural end of the reserve currency system. Then, only one money unit would rule globally without any exchange rate and with the technology advancement, a new dimension added to the discussion where, the Paper money belongs to the past. The future will be free from coined and paper money. (Dobija, M. 2014).

Amidst above discussions, the rise of Bitcoin and similar cryptocurrencies may pose a serious threat to USD as this is as an alternative to existing World currencies including USD, due to its features. Bitcoin, the first crypto-currency was invented by Satoshi Nakamoto and introduced as open-source software in 2009 as a peer-to-peer system where users can transact directly without needing an intermediary. Bitcoin often described as the first decentralized digital currency (Satoshi Nakamoto, 2008). Bitcoin currently has a market capitalization of around USD 5.9 Billion and continues to grow, subject to exchange rate stability, as more and more Bitcoins mined every day.

Bitcoin started to make its presence felt in global finance during late 2013 and early 2014. The "pseudo currency" which was launched a few years earlier by computer hobbyists, and in late 2013 the USD exchange rate for one Bitcoin (BTC) rose more than five times in the short span of a few weeks. When it began trading in 2010, its market value was less than five cents per US Dollar, which had exceeded USD 1,200.00 during 2013. (U.S. Senate Committee on Homeland Security and Governmental Affairs 2013)

David Yermack explains the global economic scenario in his paper. For most of the last two centuries, the world's powerful currencies were convertible into fixed amounts of gold or other precious metals, and for thousands of years before that, many currencies were minted directly from gold or silver species. The gold standard collapsed in most economies between the 1920s and 1970s, partly due to the pressures of financing two World Wars, but even more because it appears worldwide production of gold did not keep pace with economic growth. Since then, nearly every major economy has issued paper currency, the value of which relies on nation's government or central bank will not increase the supply of new banknotes too rapidly. Multinational associations have issued currency like the EURO on related terms. Fiat currencies have been in circulation for numerous years, and sooner or later nearly all of them have been inflated down to triviality by governments faced by constrained public finances. (David Yermack, 2014)

Bitcoin as an option, which can overcome the challenges of both Gold standards as well as fiat currencies. A virtual currency, which has a limited supply and that too tied to mathematical programming, which can be adjusted i.e. increased or decreased to maintain the rate of supply. It's done without any intervention from the government or any intermediate agency. Instead, it provides for the rate of seigniorage to slow asymptotically to zero by the year 2140 , when the last Bitcoin will be released and the final total will be fixed at 21 million units. It is well known to the public at large, the quantities as well as the growth rates of Bitcoins with certainty, so its circulation cannot be affected by monetary policies.

The review of the literature reveals that while the study of Bitcoin on a standalone basis is done exhaustively, there is a lot of scopes to do a comprehensive research covering all the aspects of Bitcoin in its current state and how the users would like to see. Bitcoin explored by the financial systems, financial Institutions, businesses around the world and most importantly the regulators. The current scenario suggests there is a lot of opportunities available in the field of cryptocurrency and that Bitcoin is the front-runner. However, the technology needs utilization in a manner that we see a new legitimate cryptocurrency, which is recognized and accepted globally, i.e. Single Global Currency which is borderless and without any exchange rates.

\section{Survey of Literature and Theoretical Development}

The literature review grouped under the variables considered for this research study. The dependent variable is the Impact of Bitcoin on USD, a world currency. Four independent variables have been identified i.e.(1) Regulation around Bitcoin globally or lack of it (2) Technology, which ensures security and privacy of the financial transactions and at the same time is very cost effective (3) Economy, which is ever increasing for Bitcoin; and (4) Bitcoin as a Currency.

Table\#1 illustrates the flow of research over the last few years, since Bitcoin came into existence and the additional value this research paper would add in understanding multiple aspects in the global finance. 
Table 1.

\begin{tabular}{|c|c|c|c|c|c|}
\hline Author & Regulation & Technology & Economy & Currency & $\begin{array}{l}\text { Impact on } \\
\text { USD }\end{array}$ \\
\hline $\begin{array}{l}\text { Satoshi Nakamoto } \\
\text { (2008) Bitcoin: A } \\
\text { Peer-to-Peer } \\
\text { Electronic Cash } \\
\text { System }\end{array}$ & $\begin{array}{l}\text { Absence of } \\
\text { Central Governing } \\
\text { Authority }\end{array}$ & $\begin{array}{l}\text { An electronic } \\
\text { transactions } \\
\text { systems relying } \\
\text { on } \\
\text { cryptographic } \\
\text { proof instead of } \\
\text { trust }\end{array}$ & N/AS & $\begin{array}{l}\text { Digital Currency which } \\
\text { can operate even in the } \\
\text { absence of financial } \\
\text { Institution } \\
\text { Intermediary }\end{array}$ & N/A \\
\hline $\begin{array}{l}\text { Plassaras, } \\
2013 . \quad \text { N.A., } \\
\text { Digital Currencies: } \\
\text { Bringing Bitcoin } \\
\text { within reach of the } \\
\text { IMF. Chicago } \\
\text { Journal } \\
\text { International of } \\
\text { Law, 14(1), pp. } \\
\text { 377-407. }\end{array}$ & $\begin{array}{l}\text { The article } \\
\text { describes the Role } \\
\text { of IMF in } \\
\text { Regulating } \\
\text { Currencies and } \\
\text { puts forward } \\
\text { suggestions on } \\
\text { how to bring } \\
\text { Bitcoin within } \\
\text { IMF's purview }\end{array}$ & $\begin{array}{l}\text { The author } \\
\text { discusses the } \\
\text { basic } \\
\text { technology and } \\
\text { its functioning }\end{array}$ & N/A & $\begin{array}{l}\text { The author presents the } \\
\text { pros and cons of the } \\
\text { digital currency }\end{array}$ & N/A \\
\hline $\begin{array}{l}\text { Christian Beer, Beat } \\
\text { Weber1,2014, } \\
\text { Bitcoin - The } \\
\text { Promise and Limits } \\
\text { of Private Innovation } \\
\text { in Monetary and } \\
\text { Payment Systems }\end{array}$ & $\begin{array}{l}\text { The article } \\
\text { highlights the } \\
\text { opinions of the } \\
\text { Regulators and the } \\
\text { Governments } \\
\text { especially } \\
\text { European Central } \\
\text { Bank, the } \\
\text { European Banking } \\
\text { Authority and } \\
\text { other regulators in } \\
\text { European } \\
\text { countries like } \\
\text { Austria, Italy and } \\
\text { France. }\end{array}$ & $\begin{array}{l}\text { Authors } \\
\text { describes the } \\
\text { basic } \\
\text { functionality of } \\
\text { Bitcoin and how } \\
\text { it operates from } \\
\text { a Technology } \\
\text { standpoint }\end{array}$ & N/A & $\begin{array}{l}\text { This paper also touches } \\
\text { upon the role of } \\
\text { Bitcoin in the Payment } \\
\text { System as well as the } \\
\text { monetary system }\end{array}$ & N/A \\
\hline
\end{tabular}




\begin{tabular}{|c|c|c|c|c|}
\hline $\begin{array}{l}\text { Casey, M.J. and } \\
\text { Vigna, P., 2015, Jan } \\
\text { 23. Bitcoin and the } \\
\text { Digital-Currency } \\
\text { Revolution; For all } \\
\text { bitcoin's growing } \\
\text { pains, it represents } \\
\text { the future of money } \\
\text { and global finance. } \\
\text { Wall Street Journal } \\
\text { (Online). }\end{array}$ & N/A & N/A & $\begin{array}{l}\text { Authors' } \\
\text { talks about } \\
\text { Investors as } \\
\text { Netscape } \\
\text { founder Marc } \\
\text { Andreessen } \\
\text { and LinkedIn } \\
\text { founder Reid } \\
\text { Hoffman } \\
\text { putting } \\
\text { millions of } \\
\text { dollars into } \\
\text { bitcoin-related } \\
\text { projects in the } \\
\text { US, including } \\
\text { the New York } \\
\text { Stock } \\
\text { Exchange and } \\
\text { the venture } \\
\text { arm of the } \\
\text { Spanish } \\
\text { banking giant } \\
\text { Banco Bilbao } \\
\text { Vizcaya } \\
\text { Argentaria } \\
\text { SA. }\end{array}$ & $\begin{array}{l}\text { Article highlights the N/A } \\
\text { differences between the } \\
\text { Traditional Banking } \\
\text { transactions } \\
\text { Cryptocurrency } \\
\text { transactions }\end{array}$ \\
\hline $\begin{array}{l}\text { Hochstein, M., } 2015 \text {, } \\
\text { Jan 29. The } \\
\text { Cryptocurrency that } \\
\text { Dares Not Speak Its } \\
\text { Name. American } \\
\text { Banker(15). }\end{array}$ & $\begin{array}{l}\text { The author } \\
\text { articulates how the } \\
\text { Federal Reserve's } \\
\text { white paper } \\
\text { considers Bitcoin } \\
\text { as a potential for } \\
\text { real-time } \\
\text { payments in the } \\
\text { banking system. }\end{array}$ & $\begin{array}{l}\text { It is highlighted } \\
\text { that the } \\
\text { proposed design } \\
\text { option of } \\
\text { cryptocurrency } \\
\text { which is not } \\
\text { same as Bitcoin, } \\
\text { it has features } \\
\text { like (a) } \\
\text { Individual Users } \\
\text { vs Financial } \\
\text { Institutions and } \\
\text { (b) Blockchain } \\
\text { vs. Central } \\
\text { Ledger }\end{array}$ & N/A & $\begin{array}{l}\text { The new currency will N/A } \\
\text { lose the features of } \\
\text { Bitcoin and will be } \\
\text { similar to fiat currency } \\
\text { except for its virtual } \\
\text { existence. }\end{array}$ \\
\hline
\end{tabular}




\begin{tabular}{|c|c|c|c|c|c|}
\hline $\begin{array}{lr}\text { Burnett, John, } 2015 . \\
\text { The New } & \text { Currency } \\
\text { Dilemma., } & \text { U.S. } \\
\text { News } & \text { Digital } \\
\text { Weekly } & 2 / 6 / 2015, \\
\text { p16-16 } & \end{array}$ & $\begin{array}{l}\text { The companies } \\
\text { operating as a } \\
\text { Virtual Currency } \\
\text { Exchange does not } \\
\text { have appropriate } \\
\text { license to operate. } \\
\text { New York } \\
\text { Department of } \\
\text { Financial Services, } \\
\text { is developing a } \\
\text { specialized } \\
\text { BitLicense. This } \\
\text { License will set } \\
\text { the terms under for } \\
\text { companies to } \\
\text { operate as a } \\
\text { bitcoin exchange } \\
\text { or broker. }\end{array}$ & N/A & $\begin{array}{l}\text { The article } \\
\text { also talks } \\
\text { about How } \\
\text { Venture } \\
\text { Capitalist is } \\
\text { investing } \\
\text { millions in } \\
\text { Bitcoin-related } \\
\text { Companies } \\
\text { like Coin base } \\
\text { Inc. Coin base } \\
\text { Inc. opened a } \\
\text { bitcoin trading } \\
\text { system } \\
\text { (Bitcoin } \\
\text { Exchange) } \\
\text { with more } \\
\text { than \$100 } \\
\text { million }\end{array}$ & $\begin{array}{l}\text { The literature discusses } \\
\text { virtual currency, an } \\
\text { innovation from the } \\
\text { high-tech world, which } \\
\text { allows people in the } \\
\text { U.S. and the rest of the } \\
\text { world to send money } \\
\text { instantly without } \\
\text { banks, credit card } \\
\text { companies or other } \\
\text { financial } \\
\text { intermediaries. }\end{array}$ & N/A \\
\hline $\begin{array}{l}\text { Tsukerman, Misha, } \\
\text { July 2015, } \\
\text { Forthcoming.The } \\
\text { Block Is Hot: A } \\
\text { Survey of the State } \\
\text { of Bitcoin } \\
\text { Regulation and } \\
\text { Suggestions for the } \\
\text { Future (March 30, } \\
\text { 2015). Berkeley } \\
\text { Technology Law } \\
\text { Journal, Vol. 30, }\end{array}$ & $\begin{array}{lr}\text { Bitcoin } & \text { and } \\
\text { Blockchain } & \\
\text { Technology } & \text { pose } \\
\text { some re novel } & \text { regulatory and } \\
\text { legal issues. This } \\
\text { paper examines } \\
\text { how government } \\
\text { agencies and } \\
\text { courts have } \\
\text { attempted to keep } \\
\text { society safe from } \\
\text { Bitcoin and } \\
\text { Blockchain users }\end{array}$ & $\begin{array}{l}\text { The author has } \\
\text { articulated } \\
\text { various } \\
\text { technological } \\
\text { aspects of the } \\
\text { Bitcoin. }\end{array}$ & N/A & $\begin{array}{l}\text { The author states the } \\
\text { existing and the } \\
\text { potential uses of } \\
\text { Bitcoin including the } \\
\text { negative aspects of } \\
\text { Bitcoin like Black } \\
\text { Markets and Tax } \\
\text { evasion. }\end{array}$ & A \\
\hline This research paper & $\begin{array}{l}\text { The anticipated } \\
\text { changes in the } \\
\text { Regulation and the } \\
\text { positive impact on } \\
\text { the virtual } \\
\text { currency. }\end{array}$ & $\begin{array}{l}\text { The } \\
\text { crypto-currency } \\
\text { technology can } \\
\text { be utilized to } \\
\text { come up with } \\
\text { the legitimate } \\
\text { currency. }\end{array}$ & $\begin{array}{l}\text { The Bitcoin } \\
\text { Economy } \\
\text { continues to } \\
\text { grow and is } \\
\text { gaining } \\
\text { massive } \\
\text { support }\end{array}$ & $\begin{array}{l}\text { Understanding Bitcoin } \\
\text { as a currency in its } \\
\text { current form and } \\
\text { whether in its current } \\
\text { form or with certain } \\
\text { positive changes if it } \\
\text { can become a } \\
\text { mainstream currency, } \\
\text { which is freely } \\
\text { available and } \\
\text { acceptable to everyone }\end{array}$ & $\begin{array}{l}\text { Studies the } \\
\text { core } \\
\text { variables } \\
\text { which has a } \\
\text { potential to } \\
\text { impact the } \\
\text { USD in the } \\
\text { global } \\
\text { finance }\end{array}$ \\
\hline
\end{tabular}

\subsection{Research Methodology}

After an exhaustive literature survey, the research methodology has been centered on the identified existing core variables. Consequently, a simple direct relationship of these four core variables has been used to create the research model to understand which of them is the most dominant.

To quantify the data, a detailed questionnaire was used to gather the formal data (primary data) from the Finance and Banking Professionals, Bitcoin enthusiasts, existing and potential Bitcoin users globally. The sample size collected was 208 during the first half of 2015. 
A tool based on structural modeling, ADANCO 1.1.1 was used to build, run and validate the process model. For analysis of the latent constructs, Partial least square (PLS) regression techniques were used. This tool ADANCO 1.1.1 is capable of exhibiting both the measurement model (outer model) and the structural model (inner model).

\subsection{Research Framework with a Model and Hypothesis Definition}

Fig. \#1 depicts the research framework ..

The impact on USD the dependent variable, The scope of research restricted to the understanding of the impact on USD as a World currency, whose position is already challenged few times by various other currencies like Yen, EURO or Chinese Yuan, but in vain. This research aims to view a new form of currency, virtual currency - Bitcoin, posing a similar threat to USD and that with certain improvement in its form, especially around regulations; it can be a real challenge.

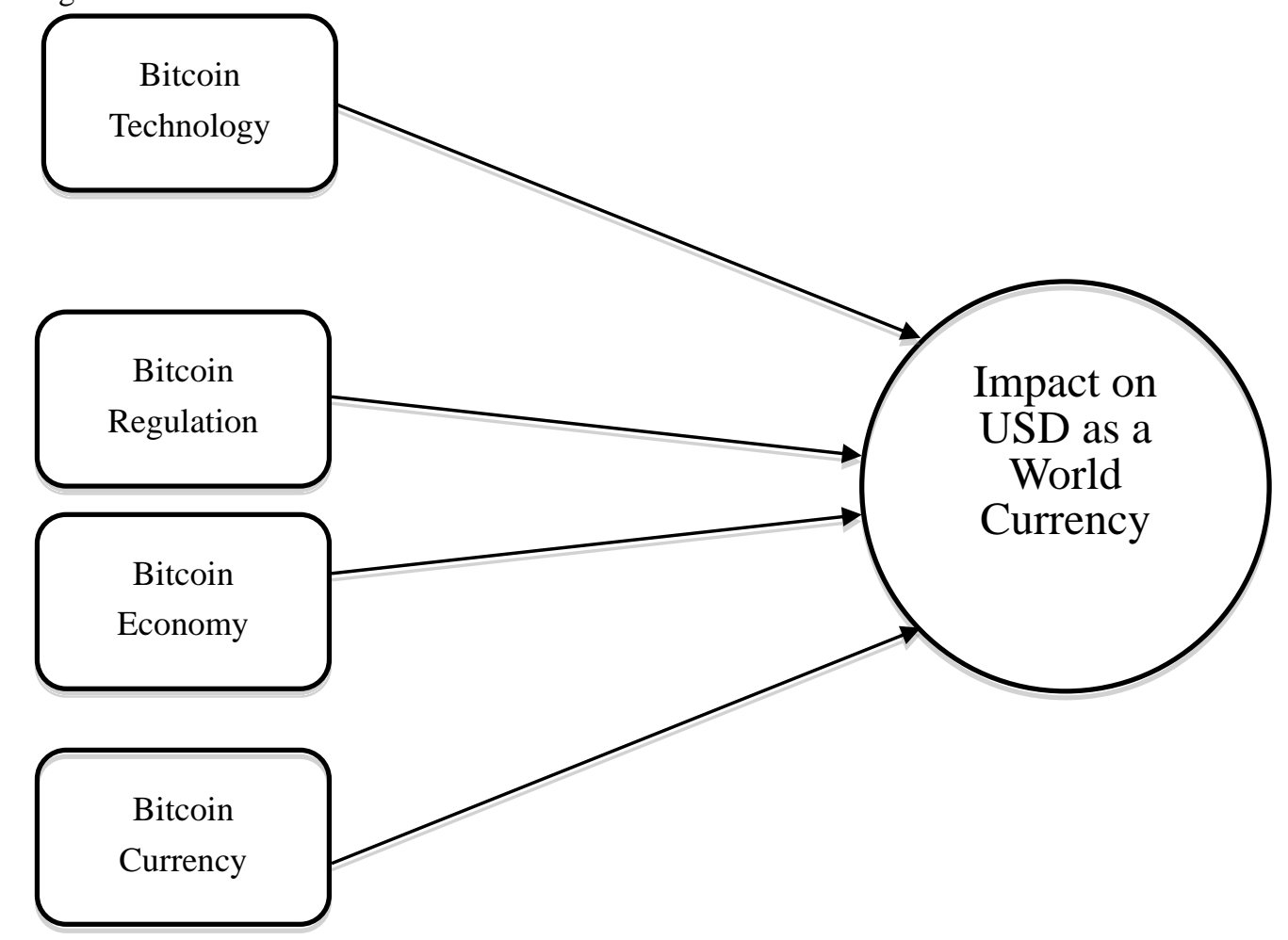

Figure 1. Research Framework

\subsubsection{Bitcoin Regulation}

As far as the regulation on Bitcoin is concerned, there is no consistency in a way various countries deal with Bitcoin. There is no consistency in guidance on the legal, accounting, tax and audit-related standards. Thus, Regulation has become one of the most debated issues facing the digital currency industry. Bitcoin technology has many of the unique and unprecedented features that give it the potential to be disruptive and impacting a broad range of industries and institutions. The ability to send money anywhere in the world in minutes, its peer-to-peer decentralized nature of value transfer and its completely digital existence, makes effective regulation of digital currencies so challenging for governments and policymakers have no clear legislation on digital currencies, which makes the process even more complex.

Government bodies, Central Banks and Regulators have started to publish opinions on Bitcoin. These publications discuss the risks of Bitcoin (e.g. to costumers or financial stability), potential regulatory responses or the legal and fiscal classification of Bitcoin.

In Europe, both the European Central Bank and the European Banking Authority discuss the risks of Bitcoin and potential regulatory stand. The ECB is focused on aspects relevant from central bank's perspective, i.e. risk to price stability, financial stability, the payment system, and reputational risks for central banks. In summary, the ECB concludes that virtual currency schemes do not pose significant risks, because of their relatively low volume and limited interrelation with the real economy. Nonetheless, this could change if cryptocurrency schemes became more important and their use more extensive. The ECB further states that, as payment systems, virtual currency schemes 
fall under the purview of central banks and therefore they also need to take into account probable Reputational Risks as central banks may be held responsible by the public for incidents involving Bitcoins. (Christian B \& Beat W, 2014)

Several institutions globally have warned consumers against using or investing in Bitcoins, stressing the risks involved. The warning by the EBA (2013), insists that regulation does not protect users of Bitcoin and that the value of Bitcoins may not remain stable. The EBA (2013) discusses potential losses due to fraud, for example, hacking of the digital wallets and advises consumers to take care of potential tax liabilities resulting from the use of virtual currencies. In Austria, the warnings of the EBA reiterated by the FMA (2014). Similar warnings issued by the Banca d'Italia (2014) and the Banque de France (2013).

The views of the major regulators like World Bank, International Monetary Fund or even Federal Reserve that are in a position to influence the world on the position of Bitcoin are not consistent.

In World Bank's view, the abstract nature of Bitcoin poses a challenge to regulators. Like any form of monetary value, including cash, e-money, and credit cards, Bitcoin can be used for both legitimate and illicit purposes. The question is whether Bitcoin makes it easier for criminals to funnel money for illicit purposes, and how regulators should respond to these perceived or real risks. (Sarah R., 2014)

In general Regulatory bodies view Bitcoin in a negative light, for example, World Bank's Research paper compared Bitcoin to a Ponzi scheme where it was highlighted 'Bitcoin is not a deliberate Ponzi'. On the positive side the paper also suggested that turn out to be the lessons it offers to central banks on the prospects of electronic currency, and on how to enhance efficiency and cut transactions cost. (Kaushik B., 2014)

FED in its White paper considers cryptocurrency like Bitcoin as a potential for real-time payments in the banking system. However, the proposed design of an ideal cryptocurrency is not same as Bitcoin. The key distinguishing features are Individual Users vs. Financial Institutions and Blockchain vs. Central Ledger. Meaning, it necessarily wants to retain the control of the cryptocurrency and unlike Bitcoin this will be centralized. (Federal Reserve System, Strategies for Improving the U.S. Payment System, January 26, 2015)

Another important aspect from the users' viewpoint is that if they can get some comfort, in the form of some Guarantee or Protection E.g. Consumer Protection Laws on Bitcoin or Crypto-Currency. Unlike fiat currency there is no government backing and therefore no guarantee on this pseudo currency. However, there are no regulations or consumer protection available for any such virtual currency including Bitcoin. Any positive indication in this direction will impact the usage and adoption of Bitcoin positively.

Hypothesis: 1 (H1). Using Bitcoin technology to become a legitimate currency will have a positive effect on the adoption and usage of Bitcoin.

Hypothesis: 2 (H2). Regulation around the Bitcoin economy will help the growth of Bitcoin in E-commerce, which in turn will also boost the growth of the Bitcoin-related service providers.

Hypothesis: 3 (H3). Bringing Bitcoin within the purview of regulation of the Central Bank and International Regulatory Bodies will have a very a positive effect regarding adoption of Bitcoin as a mainstream currency.

\subsubsection{Bitcoin Technology}

Bitcoin Technology is complex and not easy to comprehend by a layperson. It could be one reason why new user or public at large are still not comfortable to use this technology. Though, this technology existed and used in multiple areas. The Bitcoin transaction process uses cryptography to verify transactions, process payments, and control the supply of Bitcoins. The particular cryptographic schemes implemented in the Bitcoin protocol are not new and are used in a wide range of information security applications. Bitcoin relies on two cryptographic schemes (a) digital signature, which enables the exchange of accurate (payment) instructions between the parties of a transaction, and $(b)$ cryptographic hash function, which is used to enforce discipline in writing transaction, records in the public ledger. Neither of these schemes is unique to Bitcoin; they are widely used to secure commercial and government communications. (Anton B. \& Matthew C., 2014)

Not all Bitcoin users will themselves indulge in "Mining" this could be a lack of knowledge on solving the algorithms or the absence of high-speed computing machines or both. However, they clearly understand the advantages of this technology, which is mainly privacy, security and low transactions cost. Thus, as an alternate they need ample of access points where they can convert their fiat currencies into Bitcoin in the form of Bitcoin ATMs or Online conversion services with or without Bank's or Financial Institutions involvement.

Hypothesis: 4 (H4). Crypto-Currency technology makes it easy, convenient, and cost-effective to transfer Bitcoin. 


\subsubsection{Bitcoin Economy}

Over a period, it's seen that some high-profile online retailers begin accepting payments in Bitcoin, and the rise of solid and reliable payment service options looks to make coming years a game-changer for Bitcoin as an e-Commerce currency. It is evident from that fact that that we see huge Venture Capital Investments in Bitcoin-related startups, especially, Internet pioneers are betting on a bright future for Bitcoin. Investors such as Netscape founder Marc Andreessen and LinkedIn founder Reid Hoffman put $\$ 315$ million into Bitcoin-related projects in 2014 which triple the venture-capital investment of 2013, according to the digital currency news site Coindesk. Digital wallet provider Coinbase had announced of a $\$ 75$ million injection of new funds by investors including the New York Stock Exchange and the venture arm of the Spanish banking giant Banco Bilbao Vizcaya Argentaria SA. Bitpay and Bitfury were the two biggest VC deals in the second quarter of 2014 which was for $\$ 30$ million and $\$ 20$ million respectively.

There was a tremendous growth in the Bitcoin Ecosystem start-ups in 2014 with the Service providers (a) Wallet Service providers (b) Bitcoin Exchanges (c) Payment Processing (d) Financial Services (e) Mining and (f) Universal service providers, which provides all the services mentioned previously. Bitcoin's price is now on Yahoo Finance, Google Finance and Bloomberg. Merchants earlier were reluctant and didn't want to be first. Companies like Virgin Airlines and Alibaba's AliExpress have started accepting payments in Bitcoin. However, with major organizations such as Microsoft and PayPal taking leads, the virtual currency is gaining ground and now it's very much clear that Bitcoin is here to stay. For example, in Sep 2014, PayPal announced that it was partnering with Bitcoin processors Coinbase, BitPay and GoCoin to allow its merchants to accept the crypto-currency for digital goods like online games and downloadable songs.

Towards the end of 2014, around 63,000 merchants were accepting Bitcoins with the majority in online Business that includes companies like Dish Network, Expedia and newegg.com.

Merchants want a global customer base. Overstock.com reports that $60 \%$ Bitcoin users are new customers and CheapAir.com states that $100 \%$ of Bitcoin users are new to the site. At the same time, the Cyber Source online fraud report finds that the average merchant is declining roughly $8 \%$ of all international orders due to fear of chargebacks. With Bitcoin payments there are no cross-border fees, making Bitcoin especially suited to the needs of international buyers and sellers. Bitcoin continues to help the global economy in its borderless form.

Bitcoin claims to operate a retail payment system with no need for trusted intermediaries. Banks and Financial Institutions as an intermediary only end up taking huge charges in the form of fees. There is a sustained growth in all the Bitcoin-related support system to eliminate such intermediaries. The numbers of Bitcoin ATMs have grown over 500 by the end of 2015 with North America itself having over 280 ATMs i.e. over 56\% of total ATMs globally (coinatmradar.com.2017).

The Bitcoin system strives to ensure the integrity of the payment system concentrate on counterfeit control and securing anonymity. Bitcoin attempts to digitally mimic cash regarding anonymity, payment finality, transaction costs and decentralized operation of transfers. (Christian B \& Beat W, 2014). It attracts merchants to go for Bitcoin, which not only help reduce the cost but also, get new customers. Multinational Banks are concerned the way Bitcoin is making inroads in the financial system and are impacting their business. They are forced to be innovative and come up with an alternative for their survival. They are teaming up to come up with Bitcoin alternative using blockchain technology.

Hypothesis: 5 (H5). The increase in the number of services providers (Bitcoin exchanges, Wallet Services, Hedge Funds, etc.) and the merchants accepting Bitcoin has a positive effect on using Bitcoin as a virtual currency.

\subsubsection{Bitcoin as a "Currency"}

In earlier times, the currency was essentially a receipt for a commodity redeemable in most cases for physical gold. Today, however, the majority of currencies are known as "fiat" currencies, meaning these currencies are neither inherently valuable nor redeemable for a commodity but, instead, are issued and backed by some central authority such as the United States Federal Reserve. The value of such currencies derived from the trust placed in the central authority by the users of the currency.

In economics, money defined by three functions - a unit of account, means of payment and store of value. Even in a current economic scenario, there is a single unit of account in every currency territory, which is considered to be an efficient solution. Having all prices in a currency area denominated in the same unit makes them comparable and enables the operation of markets. Typically, means of payment issued as official currency by a regulatory body, which is a central bank for that country which is in charge of ensuring the quality and quantity of that money 
according to a public mandate. In most countries, such a mandate necessitates ensuring the functioning of these means of payment as a stable and most liquid store of value over the short to medium term.

While Bitcoin represents one of many private means of payment, it entails three peculiarities: It introduces a separate unit of account, it has no single and identified issuer and its quantity is ultimately fixed once and for all. Built around the model of gold, the Bitcoin is a pure asset not related to credit creation processes. It has no central issuer and does not represent anybody's liability. It implies that its quantity cannot be adjusted to variations in demand, and it does not come with anybody's promise to convert it into official currency at a certain rate. Given its operation based on crypto- graphic mechanisms described above, the term "crypto-currency" has been introduced to characterize Bitcoin-type systems. Bitcoin governance is not completely decentralized: There is the Bitcoin Foundation, which describes its tasks as standardization (e.g. funding the Bitcoin infrastructure, including a core development team), protection (e.g. maintenance, improvement and legal protection of the integrity of the technical protocol underlying the operation of Bitcoin) and promotion of the Bitcoin system, but does not represent the issuer of the currency. Whereas central banks' role in the monetary and payment system is based on a legal mandate of the policy of the currency area and its ability to issue currency, the Bitcoin Foundation lacks such ingredients and therefore cannot fulfill the role of a central bank. Indeed, deliberately designing a system without a central bank is one of the cornerstones of the Bitcoin concept. (Christian B \& Beat W, 2014)

Being nobody's liability is a feature the Bitcoin shares with gold. But in contrast to gold, which is customarily used for various products (e.g. electronics, industry, dental fillings or jewelry) and has a commodity value, the Bitcoin has no use value other than serving its role in the Bitcoin system. Therefore its value is determined only by the subjective valuation of users, exhibiting substantial volatility regarding official currency. The fixed increase, up to a predefined final level, of supply makes demand effects dominant. This has led some observers to invoke the "greater fool theory" as the basis for the Bitcoin's valuation (Blundell- Wignall, 2014, p. 9). From a store of value standpoint, the Bitcoin can be better characterized as a speculative asset. Given this, economic incentives for hoarding are far greater than incentives for spending Bitcoins. Exceptions are transactions where using official currency is not applicable or disadvantageous (e.g. illicit transactions and small-denomination online payments).

According to Sagendorf (2014, p. 79), the trade appears to be restrained to a mere $4 \%$ of all Bitcoin holdings are traded within one week and $24 \%$ within three months. It takes six months for some 50\% to be traded, and about $38 \%$ are held for more than one year. Gandal and Halburda's (2014) observations on market developments in competing crypto-currencies confirm this assessment. Some cryptos- currencies have emerged in the wake of Bitcoin, most of them modeled after the latter with small variations in design. If there were an emerging market for crypto-currency as a substitute for money, network effects would entail a winner-takes-it-all dynamic. But although Bitcoin was the first and is by far the largest network regarding market capitalization, several hundred competitors have since then been established by various entities and some have succeeded in gathering some support. It could be considered evidence that the financial asset function is a more prominent motive than currency adoption among users.

Hypothesis: 6 (H6). Bitcoins availability as a currency has a positive impact on its usage and it will affect the future of the World Currencies like USD.

\section{Methodology}

In forming the four core variable, the literature review was used as a source of the secondary data. A detailed discussion is captured in the literature survey section earlier. For primary analysis survey data was collected from 208 respondents.

\subsection{Data Collection}

The survey included both - qualitative as well as quantitative questions for latent constructs. Based on the inputs and feedback, the final survey questionnaire was designed. Finance and Banking Professionals, Bitcoin enthusiasts, existing and potential Bitcoin users globally were survey respondents.

Further, for each latent construct, three to five questions (indicators) were formulated capturing the current and the future state of Bitcoin and the corresponding effect on USD as a World Currency. The responses were measured on a 5-point Likert scale using scales from strongly disagree to agree strongly. The last section of the survey captured the demographic details of the respondents. The data were collected through an online survey (via Google Docs). By the cut-off, there were 208 complete and usable responses. Table\#2 below summarizes the demographic characteristics of the respondents of this survey. 
Table 2. Demographic Characteristics

\begin{tabular}{|c|c|c|}
\hline Demographic Characteristics of the Participants $(\mathrm{n}=208)$ & No. & $\%$ \\
\hline \multicolumn{3}{|l|}{ Gender } \\
\hline Female & 69 & $33.2 \%$ \\
\hline Male & 139 & $66.8 \%$ \\
\hline \multicolumn{3}{|l|}{ Age } \\
\hline $21-30$ & 44 & $21.2 \%$ \\
\hline $31-40$ & 115 & $55.3 \%$ \\
\hline $41-50$ & 43 & $20.7 \%$ \\
\hline Above 50 & 6 & $2.9 \%$ \\
\hline \multicolumn{3}{|l|}{ Industry } \\
\hline Accounting / Audit / Law firm & 20 & $9.6 \%$ \\
\hline Banking /Finance & 61 & $29.3 \%$ \\
\hline Chemicals & 5 & $2.4 \%$ \\
\hline Data Centre & 10 & $4.8 \%$ \\
\hline Electronics Products & 10 & $4.8 \%$ \\
\hline Engineering and Construction & 6 & $2.9 \%$ \\
\hline Food and Beverage & 5 & $2.4 \%$ \\
\hline Healthcare and Medical Products & 8 & $3.8 \%$ \\
\hline Information Technology & 44 & $21.2 \%$ \\
\hline Logistics & 12 & $5.8 \%$ \\
\hline Machinery and Equipment & 7 & $3.4 \%$ \\
\hline Others & 20 & $9.6 \%$ \\
\hline
\end{tabular}

Designation

\begin{tabular}{lll}
\hline Assistant Vice President / Assistant /Director / Vice President / Director & 60 & $28.8 \%$ \\
\hline Associate / Assistant Manager / Manager / Senior Manager & 97 & $46.6 \%$ \\
\hline Junior / Executive level & 29 & $13.9 \%$ \\
\hline Managing Director / General Manager & 15 & $7.2 \%$ \\
\hline Owner / Chairman / President / CEO / COO & 7 & $3.4 \%$ \\
\hline & & \\
\hline Annual Income (in USD) & 8 & $3.8 \%$ \\
\hline Less than 10,000 & 31 & $14.9 \%$ \\
\hline 10,000 - 25,000 & 34 & $16.3 \%$ \\
\hline 26,000 - 50,000 & 51 & $24.5 \%$ \\
\hline 51,000 - 75,000 & 40 & $19.2 \%$ \\
\hline $76,000-99,000$ & 44 & $21.2 \%$ \\
\hline 100,000 \& above & & \\
\hline & & \\
\hline Region & 100 & $48.1 \%$ \\
\hline Asia Pacific & 43 & $20.7 \%$ \\
\hline Europe & 45 & $21.6 \%$ \\
\hline Middle East \& Africa & 20 & $9.6 \%$ \\
\hline North \& South America & &
\end{tabular}




\section{Statistical Techniques/Tools for Data Analysis}

SEM (Structural Equation(s) Modeling) is a statistical technique for simultaneously testing and estimating causal relation- ships among multiple independent and dependent constructs. Exploratory factor analysis (EFA) using ADANCO 1.1.1 has been used for the initial set of 30 respondents. EFA was used to uncover the underlying structure of the five core variables. The assumption was that any independent factor could be more associated. There is no prior theory in EFA. Later, for 193 respondents, CFA (Confirmatory Factor Analysis) has been used.

\subsection{Data Analysis}

PLS (Partial Least Square) technique has been used to validate the measurements and to test thesis hypotheses using ADANCO 1.1.1 software. The PLS technique uses component-based approach for model estimation and is very much suitable for testing complex structural models. The reason why PLS technique was selected was that it does not impose any normality requirements on the data. A two-step approach has been used first to assess the quality of measures (as per this Bitcoin-related research study) using the measurement model (outer model), and then to test the hypotheses using the structural model (inner model) (SEM stage, Joreskog \& Sorbom, 1993), this is as per the recommendation by Segars and Grover (1993). ADANCO 1.1.1 uses latent variables for the path modeling. This tool is also used to measure the validity and reliability of the constructs. In addition to PLS Algorithm, Bootstrapping is used with 193 cases to generate the standard error of the estimate and t-values.

\section{Discussion, Analysis and Findings}

An important conclusion of this research is that the Regulators may not encourage usage of Bitcoin, but the technology itself cannot be ignored as the number of cryptocurrencies are growing day by day which is replacing the fiat currencies in the markets and is forcing the financial institutions around the world to innovate and therefore Regulators will have to come into play to provide guidelines for such currencies.

The next section details, a confirmatory factor analysis (CFA) conducted to assess reliability, convergent validity and discriminant validity of the scales.

Table 3. Composite Reliability

\begin{tabular}{lllll}
\hline Construct & $\begin{array}{l}\text { Average Variance } \\
\text { Extracted (AVE) }\end{array}$ & $\begin{array}{l}\text { Composite } \\
\text { Reliability }\end{array}$ & $\begin{array}{l}\text { Cronbach's } \\
(\alpha)\end{array}$ & $\begin{array}{l}\text { alpha } \\
\text { Technology }\end{array}$ \\
\hline 0.7425 & 0.8963 & 0.8265 & $\begin{array}{l}\text { Coefficient of } \\
\text { determination }\left(\mathrm{R}^{2}\right)\end{array}$ \\
\hline Economy & 0.7873 & 0.9366 & 0.9091 & 0.7111 \\
\hline Currency & 0.8665 & 0.9285 & 0.8464 & 0.7009 \\
\hline Impact on USD & 0.7196 & 0.8848 & 0.8064 & 0.6524 \\
\hline Regulation & 0.8802 & 0.9363 & 0.8639 & 0.0000 \\
\hline
\end{tabular}

5.1 Measurement Validation and Reliability

The reliability of these related research measurements has been evaluated using Composite reliability scores and Cronbach's alpha. The constructs are considered satisfactory when the Cronbach's alpha scores are above the minimum recommended value of 0.6 (Hair, Black, Babin, \& Anderson, 2010; Malhotra, 2010; Robinson, Shaver, \& Wrightsman, 1991) and composite reliability scores are above the recommended cut-off of 0.7 (Gefen, Straub, \& Boudreau, 2000; Nunnally, 1978). Composite reliability is considered a more rigorous estimate of reliability (Chin \& Gopal, 1995). As shown in Table\#3, the composite reliability scores exceed 0.8 and Cronbach's alpha values exceed 0.7 . Thus the overall model can be considered as reliable.

\subsection{Convergent Validity}

The average variance extracted (AVE) and the values of outer loadings values to measure the validity of the model (Henseler et al., 2009). The AVE should be more than 0.5 and the outer loadings should be greater than 0.7 (Wong, 2013). Table\#4 shows the values for the outer loadings of the model and as can be seen, all the derived values are above the benchmark value and therefore, the model is considered valid (Hair et al., 2011). 
Table 4. Convergent Validity

\begin{tabular}{llllll}
\hline Indicator & Regulation & Technology & Economy & Currency & Impact on USD \\
\hline BR1 & 0.9351 & 0.7944 & 0.7232 & 0.7301 & 0.6680 \\
\hline BR2 & 0.9315 & 0.7796 & 0.7150 & 0.6883 & 0.6343 \\
\hline BT1 & 0.7210 & 0.8681 & 0.6907 & 0.5871 & 0.5605 \\
\hline BT2 & 0.7473 & 0.8401 & 0.7207 & 0.7009 & 0.6004 \\
\hline BT3 & 0.6984 & 0.8631 & 0.7109 & 0.5246 & 0.5757 \\
\hline BE1 & 0.5809 & 0.6812 & 0.8056 & 0.5503 & 0.5908 \\
\hline BE2 & 0.6842 & 0.7460 & 0.9052 & 0.7197 & 0.7870 \\
\hline BE3 & 0.6869 & 0.6613 & 0.8891 & 0.6663 & 0.6291 \\
\hline BE4 & 0.7558 & 0.8148 & 0.9262 & 0.7307 & 0.7204 \\
\hline BC1 & 0.7120 & 0.6582 & 0.7301 & 0.9336 & 0.8148 \\
\hline BC2 & 0.6956 & 0.6508 & 0.6746 & 0.9184 & 0.6603 \\
\hline IU1 & 0.6499 & 0.7629 & 0.7401 & 0.6476 & 0.8278 \\
\hline IU2 & 0.6203 & 0.5112 & 0.6632 & 0.7690 & 0.9016 \\
\hline IU3 & 0.4907 & 0.4455 & 0.5610 & 0.5952 & 0.7989 \\
\hline
\end{tabular}

\subsection{Discriminant Validity}

The discriminant validity of the factors estimates the strength of the model regarding the extent to which the measure in the model differs from other items in the same model. In the PLS technique, the discriminant validity can be confirmed by testing the correlations between the intersecting measures (Trochim, 2006). The square root of the AVE of each construct is calculated and the correlation between the measures is more than the desired value of 0.6 (Gupta et al., 2013). In Table\#5, the diagonal highlighted value shows that the value of the square root of the AVE for each of the constructs is more than the other constructs.

Table 5. Discriminant validity

\begin{tabular}{llllll}
\hline Construct & Technology & Economy & Currency & Impact on USD & Regulation \\
\hline Technology & 0.7425 & & & & \\
\hline Economy & 0.6819 & 0.7873 & & & \\
\hline Currency & 0.4994 & 0.5772 & 0.8655 & & \\
\hline Impact on USD & 0.4568 & 0.6023 & 0.6410 & 0.7196 & 0.8802 \\
\hline Regulation & 0.7111 & 0.5937 & 0.5779 & 0.4871 & \\
\hline
\end{tabular}

\subsection{Assessment of Structural Model}

ADANCO 1.1.1 software was used to examine the structural model tested the hypotheses generated out of this research; this includes estimating the path coefficients indicating the strength of the relationships between the independent variables and dependent variable and R-square value. A bootstrapping resampling procedure (Davison \& Hinkley, 1997; Efron \& Tibshirani, 1993) of 193 samples was used to determine the significance level of the paths defined within the structural model (Chatelin, Vinzi, \& Tenenhaus, 2002; Chin \& Gopal, 1995). Bootstrapping results in a larger sample, which is claimed to model the unknown population (Henderson, 2005). The corresponding $\mathrm{t}$-values show the level of significance using the magnitude of the standardized parameter estimates between the constructs. A 5\% significance level $(\mathrm{p}<0.05)$ is used as a statistical decision parameter (Fisher, 1925; Cowles \& Davis, 1982). The below Table\#8 summarizes the results of the structural model.

All six hypotheses supported with the explained variance ranging from 0.42 to 0.84 . The results for the hypotheses are as follows:

Hypothesis: H1 (31.11) Supported strongly since because with Regulator's support, the technology can be utilized to come up with the legitimate virtual currency. 
Hypothesis: H2 Supported because the path from Regulation to Economy is strongly supported (28.26) meaning positive changes in the regulation will encourage the overall Bitcoin Economy.

Hypothesis: H3 Supported strongly (20.31) because if Regulators can support BTC by bringing it in the legal framework, its role as a currency can be enhanced multiple folds.

Hypothesis: H4 Supported because the path from Bitcoin Technology to the Bitcoin Economy is significant (12.31) as users believe that Technology features are driving the increase in the Bitcoin Economy.

Hypothesis: H5 Supported (6.39) because the path from Economy to Currency which implies that with more and more Bitcoin-related services and service providers increasing, it will boost its usage as a Currency.

Hypothesis: H6 (37.05) Supported strongly with more and more Vendors accepting Bitcoin as a mode of payment for their products or services it has an adverse impact on the circulation of USD.

The following figure (Fig\#2) exhibits the findings using PLS structural modeling:

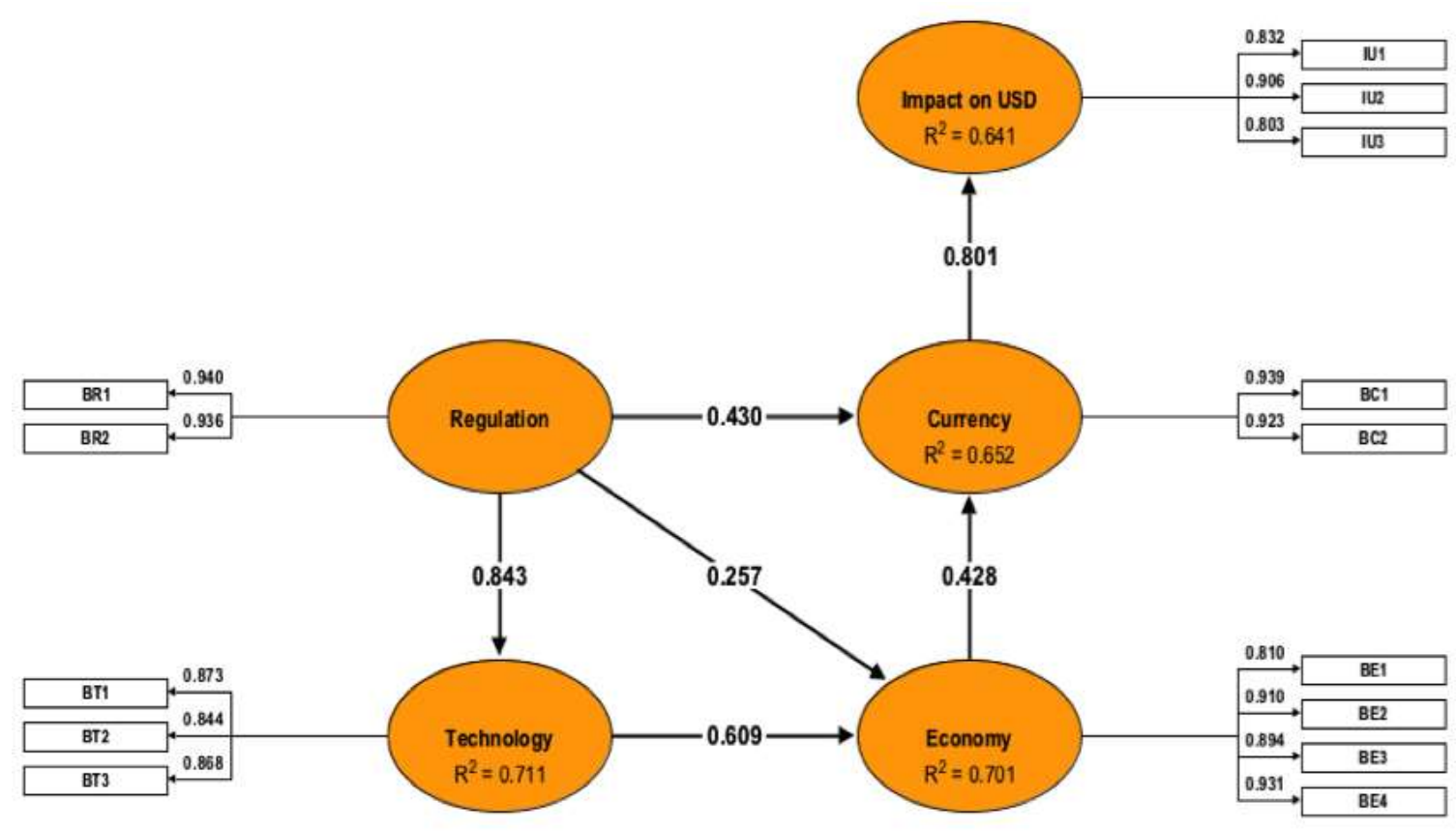

Figure 2. Results of PLS structural model analysis (ADANCO 1.1.1snapshot)

\subsection{Assessment of Fit}

In their guidelines on PLS Jörg Henseler, Geoffrey Hubona and Pauline Ash Ray (2015) explains how to assess and report PLS results, including the novel bootstrap-based tests of model fit, the SRMR as an approximate measure of (model fit, the new reliability coefficient rhoA, and the HTMT. The global model fit can be assessed in two non-exclusive ways: using inference statistics, i.e. so-called tests of model fit, or through the use of fit indices, i.e. an assessment of approximate model fit. To have some frame of reference, it has become customary to determine the model fit both for the estimated model and for the saturated model. Saturation refers to the structural model, which means that in the saturated model all constructs correlate freely.

Table 6. Goodness of model fit (saturated fit)

\begin{tabular}{llll}
\hline & Value & HI95 & HI99 \\
\hline SRMR & 0.0789 & & \\
\hline $\mathrm{d}_{\text {ULS }}$ & & & \\
\hline $\mathrm{d}_{\mathrm{G}}$ & & & \\
\hline
\end{tabular}


Table 7. Goodness of model fit (estimated fit)

\begin{tabular}{llll}
\hline & Value & HI95 & HI99 \\
\hline SRMR & 0.0948 & & \\
\hline $\mathrm{d}_{\mathrm{ULS}}$ & & & \\
\hline $\mathrm{d}_{\mathrm{G}}$ & & & \\
\hline
\end{tabular}

Table 8 . Summary of hypotheses tests (path coefficients and hypotheses testing)

\begin{tabular}{|lr|}
\hline \multicolumn{2}{l|}{ Significance values } \\
$\mathrm{p}<0.1$ & 1.652 \\
$\mathrm{p}<0.05$ & 1.971 \\
$\mathrm{p}<0.01$ & 2.599 \\
\hline
\end{tabular}

\begin{tabular}{lllll}
\hline Hypothesis & Effect & Path Coefficient & T-value & Supported \\
\hline H1 & Regulation -> Technology & 0.8433 & 31.1160 & Yes \\
\hline H2 & Regulation -> Economy & 0.7705 & 28.2625 & Yes \\
\hline H3 & Regulation -> Currency & 0.7602 & 20.3134 & Yes \\
\hline H4 & Technology -> Economy & 0.6093 & 12.3117 & Yes \\
\hline H5 & Economy -> Currency & 0.4283 & 6.3945 & Yes \\
\hline H6 & Currency -> Impact on USD & 0.8006 & 37.0580 & Yes \\
\hline
\end{tabular}

\section{Implications of Research}

The findings of this research paper are multifold. It indicates few variables like Technology with features like Security, Privacy and cost-effectiveness, along with the Bitcoin Economy are for Bitcoin users. Combined these can translate into encouraging the usage of Bitcoin as a mainstream currency competing with fiat currencies.

Also, this research indicates one variable (Regulation) that needs immediate attention by the regulators across the world. This research proves that various other inter-relationships do exist between the four core variables, which are significant, as explained by the various hypotheses above.

\section{Limitations and Scope for Further Research}

This research conducted in APAC (Asia Pacific) region. This research is limited to the in-depth study of only four (core) latent variables, supported by the existing literature survey.

The above signifies that there is tremendous scope for further research in this area, which includes further investigation into new variables.

\section{Conclusions}

Bitcoin has a huge potential, but it cannot in its current form, affect the USD though it can harm it significantly, if its exchange rate versus USD increases drastically. The reason for this conclusion is a major regulatory hurdle that Bitcoin is facing, which will not allow it to increase, the way it would have increased if it had Regulators' support. Another important aspect is the limited supply, primarily due to the limited units, i.e. 21 million. One may argue that Bitcoin is capable of reducing itself to a "Satoshi: i.e. the smallest fraction of a Bitcoin which is 0.00000001 BTC, meaning a hundredth of a millionth BTC. Again, if this fraction of BTC if has to be used in transactions, it should have some respectable value, i.e. the exchange rate with other major currencies in the world should be very high.

The positive message that can be seen is that people are willing to explore technology and is open to adopting different formats of the virtual currency provided they get some reasonable assurance that the underlying virtual currency has a regulatory backing and therefore will also have some stability in its value.

\section{References}

Akter, S., D'Ambra, J., \& Ray, P. (2011). Trustworthiness in mHealth information services: an assessment of a hierarchical model with mediating and moderating effects using partial least squares (PLS). Journal of the American Society for Information Science and Technology, 62(1), 100-116. https://doi.org/10.1002/asi.21442 
Amato, S., Esposito Vinzi, V., \& Tenenhaus, M. (2004). A global goodness-of-fit index for PLS structural equation modeling. Oral Communication to PLS Club, HEC School of Management, France, March, 24, 1-4.

Badev, A. I., \& Chen, M. (2014). Bitcoin: Technical background and data analysis.

Bayern, S. (2014). Dynamic common law and technological change: the classification of Bitcoin. Wash. \& Lee L. Rev. Online, 71, 22.

Beanland, C., (2013). Bitcoin: The New Gold Standard?. The Independent, 38. ISSN 09519467.

Becker, J., Breuker, D., Heide, T., Holler, J., Rauer, H. P., \& Böhme, R. (2013). Can we afford integrity by proof-of-work? Scenarios inspired by the Bitcoin currency. In The Economics of Information Security and Privacy (pp. 135-156). Springer Berlin Heidelberg.

Bedell, D., (2011). Same Old, Same Old. Global Finance, 25(10), pp. 1.

Bhalla, S. S. (2011). Euro and the Yuan: different peas in the same pod. Comparative Economic Studies, 53(3), 355-381. https://doi.org/10.1057/ces.2011.20

Blundell-Wignall, A. (2014). The Bitcoin question: Currency versus trust-less transfer technology. OECD Working Papers on Finance, Insurance and Private Pensions, (37), 1.

Burnett, \& John, (2015). The New Currency Dilemma U.S. News Digital Weekly, p16-16

Casey, M. J., \& Vigna, P. (2015). Bitcoin and the Digital-Currency Revolution. The Wall Street Journal, 23.

Chance, G. (2014). WILL THE PEOPLE'S CURRENCY BECOME THE GLOBAL CURRENCY?. Corporate Finance Review, 19(3), 6.

Chatelin, Y. M., Vinzi, V. E., \& Tenenhaus, M. (2002). State-of-art on PLS Path Modeling through the available software.

Chavez-Dreyfuss, Gertrude; Connor, \& Michael. (2014). Bitcoin shows staying power as retailers chase digital sparkle. Irish Independent [Dublin] 32.

Chin, W. W., \& Gopal, A. (1995). Adoption intention in GSS: relative importance of beliefs. ACM SigMIS Database, 26(2-3), 42-64. https://doi.org/10.1145/217278.217285

Christian, Beer, Beat, W. (2014). Bitcoin - The Promise and Limits of Private Innovation in Monetary and Payment Systems.

Colesanti, J. S. (2015). Trotting Out the White Horse: How the SEC Can Handle Bitcoin's Threat to American Investors.

Colesanti, J. S. (2015). Trotting Out the White Horse: How the SEC Can Handle Bitcoin's Threat to American Investors.

Cooper, J. (2015). Supplement: Report - Regulation and Strategy - New approaches to banking - Banking: the next generation. The Banker.

Cowles, M., \& Davis, C. (1982). On the origins of the. 05 level of statistical significance. American Psychologist, 37(5), 553.

David, G.H. (2013). The Evolving Bitcoin Landscape in Canada; M2 Presswire.

David, Y. (2014). Is bitcoin a real currency? An economic appraisal. New York University Stern School of Business and National Bureau of Economic Research.

Davison, A. C., \& Hinkley, D. V. (1997). Bootstrap methods and their application (Vol. 1). Cambridge university press.

Dobija, M. (2014). The Global Currency Area a Way to Constructively End the Era of Reserve Currency. Modern Economy, 05(04), 289-302. http://dx.doi.org/10.4236/me.2014.54029

Dr. Schularick (2010). Implications of the Dollar as the World Reserve Currency.

Efron, B., \& Tibshirani, R. (1993). An Introduction to the Bootstrap/by Bradley Efron, Robert J. Tibshirani (No. 519.544 E4.).

Eichengreen, B., \& Flandreau, M. (2009). The rise and fall of the dollar (or when did the dollar replace sterling as the leading reserve currency?). European Review of Economic History, 13(3), 377-411. 
Endres, A. M. (2009). Currency competition: a Hayekian perspective on international monetary integration. Journal of Money, Credit and Banking, 41(6), 1251-1263. https://doi.org/10.1111/j.1538-4616.2009.00255.x

Ferguson, N., \& Schularick, M. (2011). The End of Chimerica. International Finance, 14(1), 1-26. http://dx.doi.org/10.1111/j.1468-2362.2010.01274.x.

Fisher, R. A. (1925). Statistical methods for research workers. Genesis Publishing Pvt Ltd.

Franco, P. (2014). Understanding Bitcoin: Cryptography, engineering and economics. John Wiley \& Sons.

Fratzscher, M., \& Mehl, A. (2014). China's Dominance Hypothesis and the Emergence of a Tri - polar Global Currency System. The Economic Journal, 124(581), 1343-1370.

Frizell, Sam, 2015, Bitcoins Are Easier To Track Than You Think, Time.com 2/3/2015.

Galati, G., \& Wooldridge, P. (2009). The euro as a reserve currency: a challenge to the pre - eminence of the US dollar?. International Journal of Finance \& Economics, 14(1), 1-23.

Goodale, G.,(2014, Feb 26). Can Bitcoin Survive? Debate rages, but experts say regulation is possible. The Christian Science Monitor, 17. ISSN 08827729.

Hakkeem, M. A., \& Sha, Y. M. (2015). A study on customer satisfaction in internet banking with special reference to Tiruchirappalli district. International Journal of Marketing and Technology, 5(2), 72.

Harper, J. (2014). Bitcoin and stability. Foreign Affairs, 93(6), 241-242.

Henderson, A. R. (2005). The bootstrap: a technique for data-driven statistics. Using computer-intensive analyses to explore experimental data. Clinica Chimica Acta, 359(1), 1-26,

Henderson, A. R. (2005). The bootstrap: a technique for data-driven statistics. Using computer-intensive analyses to explore experimental data. Clinica Chimica Acta, 359(1), 1-26.

Hochstein, M., 2015, Jan 29. The Cryptocurrency that Dares Not Speak Its Name. American Banker (15). ISSN 00027561 .

Hokroh, M. A. (2013). Examining the Chinese Exchange Rate Reform and the Possibility of the Chinese Yuan Becoming a Regional Trade Currency. Research in Applied Economics, 5(3), 129.

Hooi, J., 2014, Mar 22. Bitcoin: Virtual Currency, real-world problems. The Business Times.

Hulland, J. (1999). Use of partial least squares (PLS) in strategic management research: A review of four recent studies. Strategic management journal, 195-204.

Ivanescu, M. M., \& Ivanescu, I. M. (2011). Future Perspective On The Euro As A Global Currency. Romanian Economic and Business Review, 6(1), 159.

Jacquet, N. L., \& Tan, S. (2011). Money, bargaining, and risk sharing. Journal of Money, Credit and Banking, 43(s2), 419-442.

Jamwal, M.,(2014). Betting on Bitcoin. The Asian Venture Capital Journal, 27(3), 7-9.

John Hulland. (1999). Use of Partial Least Squares (PLS) in Strategic Management Research: A Review of Four Recent Studies. Strategic Management Journal, 20(2), 195-204.

Jöreskog, K. G., \& Sörbom, D. (1993). LISREL 8: Structural equation modeling with the SIMPLIS command language. Scientific Software International.

Kalamdi, K. \& Dang, S., (2015). Virtual Currencies - Gold 2.0 or Mirage? Global Finance, 29(3), 10-13.

Kaushik Basu, (2014, July). Ponzis - The Science and Mystique of a Class of Financial Frauds, Policy Research Working Paper.World Bank.

Kun, A.A C.A.(S.A.), (2014). Bitcoin: The Currency of the Future? Accountancy SA, 34-35.

Mangin, J.L., PHD., Bourgault, N., Guerrero, M.M., PHD. And Egea, J.M.O., PHD. (2011). Modeling perceived Usefulness on adopting On-line Banking through the TAM Model in a Canadian Banking Environment. Journal of Internet Banking and Commerce, 16(1), 1-23.

Moshirian, F. (2007). Global financial services and a global single currency. Journal of Banking \& Finance, 31(1), 3-9.

O'Rourke, K. H., \& Taylor, A. M. (2013). Cross of euros. The Journal of Economic Perspectives, 27(3), 167-191. 
Perlroth, N. (2014, Apr 2). To Instill Love of Bitcoin. Backers Work to Make It Safe. New York Times. ISSN 03624331 .

Plassaras, N. A. (2013). Regulating digital currencies: Bringing Bitcoin within reach of IMF. Chi. J. Int'l L., 14, 377.

Prasad, E. and Ye, L. (2013). The Renminbi Prospects as a Global Reserve Currency. Cato Journal, 33(3), pp. 563-570.

Quah, C., \& Crowley, P. (2010). Monetary Integration in East Asia: A Hierarchical Clustering Approach. International Finance, 13(2),283-309. http://dx.doi.org/10.1111/j.1468-2362.2010.01264.x

Rayman, Noah. (2014). PACs Can Take Bitcoin, Regulator Says. Time.com 5/9/2014, 1-1.

Rivers, R. (2011, Jun 20). Facing the challenges of a strong currency. Money Management. ISSN 13227254.

Sarah Rotman. (2014, January). Bitcoin Versus Electronic Money, (WWorld Bank, CGAP, 2014.

Satoshi Nakamoto. (2008). Bitcoin: A Peer-to-Peer Electronic Cash System.

Segars, A., \& Grover, V. (1993). Re-Examining Perceived Ease of Use and Usefulness: A Confirmatory Factor Analysis. MIS Quarterly, 17(4), 517. https://doi.org/10.2307/249590

Steil, B. (2014). Taper Trouble: The International Consequences of Fed Policy. Foreign Affairs, 93(4), 54-61.

Teddy, D. (2014). The First Ever CryptoCurrency Convention Set to Explore the Future of Digital Currencies. Business Wire.

Tenenhaus, M., Vinzi, V. E., Chatelin, Y. M., \& Lauro, C. (2005). PLS path modeling. Computational statistics \& data analysis, 48(1), 159-205.

Tenenhaus, M., Vinzi, V., Chatelin, Y., \& Lauro, C. (2005). PLS path modeling. Computational Statistics \&Data Analysis, 48(1), 159-205. http://dx.doi.org/10.1016/j.csda.2004.03.005

Todd, S., 2015, Mar 04. Cryptocurrency Technology Set to Shake Up Correspondent Banking. American Banker (33). ISSN 00027561.

Tschirhart, J. (1999). General Equilibrium of an Ecosystem. Department of Economics and Finance. The university of Wyoming.

Tuckerman, Misha. (2015, July). Forthcoming. The Block Is Hot: A Survey of the State of Bitcoin Regulation and Suggestions for the Future. Berkeley Technology Law Journal, Vol. 30.

Turpin, J. (2014). Bitcoin: The Economic Case for a Global, Virtual Currency Operating in an Unexplored Legal Framework. Indiana Journal of Global Legal Studies, 21(1), 335-368. https://doi.org/10.2979/indjglolegstu.21.1.335

Weber, B. (2016). Bitcoin and the legitimacy crisis of money. Cambridge Journal of Economics, 40(1), 17-41.

Wetzels, M., Odekerken-Schroder, G., \& Van Oppen, C. (2009). Using PLS path modeling for assessing hierarchical construct models: Guidelines and empirical.

Wetzels, M., Odekerken-Schröder, G., \& Van Oppen, C. (2009). Using PLS path modeling for assessing hierarchical construct models: Guidelines and empirical illustration. MIS Quarterly, 177-195.

Wu, C.Y PHD. And Pandey, Vivek K, DBA, C.F.A F.R.M. (2014). The Value of Bitcoin in Enhancing the Efficiency of an Investor's Portfolio. Journal of Financial Planning, 27(9), 44-52.

Yaacob, S., \& Ahmad, S. (2014). Return to Gold-Based Monetary System: Analysis Based on Gold Price and Inflation. Asian Social Science, 10(7). https://doi.org/10.5539/ass.v10n7p18 